UDC 811:161.1-054.6

DOI: $10.17223 / 24109266 / 11 / 8$

\title{
DIALOGUE COMMUNICATIVE STRUCTURES IN THE PROCESS OF TEACHING FOREIGN-LANGUAGE DIALOGIC COMMUNICATION SKILLS
}

\author{
T.B. Mikheeva, M.V. Ereshchenko
}

\begin{abstract}
The interrelation between the strategical content of a dialogue and the specific character of its grammatical, lexical and syntactic arrangement remains the most important question to be answered. The simulating of lingual interaction can be used in the process of creating new systems of conditionally communicative strategic exercises for teaching dialogue. This paper represents a study of the aspects of developing effective dialogic models with due consideration of their communicative structures in the process of teaching a foreign language. The main communicative strategies and approaches applied to different multinational groups and groups with mixed age at different stages of teaching are described here. A concept of a simulated dialogue is proposed in this study. The concept means controlled conversational interaction (dialogic interaction) between persons being taught, which is composed of different dialogue partners' personal intentions implemented in coordination. Unsymmetrical contacts affect the dialogue development, where tactic forms choice limitations get involved, wider prospect of a dialogue is provided due to the equal social roles of participants interested in the perception of information communicated, and dialogue simulation ensures necessary volume of a speech interaction act. The results of a linguistic experiment conducted using the elements of conscious effect on the process of natural lingual interaction were used as material for study. The process was controlled by means of unexpected introduction of a new incentive (stimulus). The pseudocommunicativeness of such interaction was eliminated due to the availability of incentives aimed at expanding the elementary cycle through the introduction of new structural strategic components, a new aim, or a new script. Several students learning Russian as a foreign language took part in the experiment. As a result of studies undertaken a corpus of extracted dialogues was compiled. Applying the communicative tactics as a basis for teaching a foreign language the use of a simulated dialogue can promote the optimization of the teaching process and supplementary motivation in learning a foreign language as a communication tool, because the choice of an optimal way of expressing intentions is the communicative need of any person learning a language.

Key words: dialogical communication, lingual interaction simulation, communicative tactics (approaches), communicative strategies, communicative structures of a dialogue.
\end{abstract}

\section{Introduction}

The monologue predominance in the process of teaching a foreign language promotes poor development of the skills of unrehearsed speech. Just an unrehearsed dialogue is the basis for developing communicative competence. 
It is commonly believed that competence is a system of rules, which can generate an infinite number of syntactic, phonological, and semantic structures [1: 19]. The syntactic component, as one of the three main components of generative grammar, determines a set of abstract objects, which include all information necessary for the interpretation of a certain sentence. The phonological component determines a phonetic form of a sentence, and the semantic component determines semantic interpretation. Therefore, using a language means the real use of a language, i.e. competence in a certain situation. The communicative competence model of persons learning a language includes "lingual, speech, strategic, sociocultural, conversational (discursive), social, pragmatic, intellectual, and personal competence" [2: 261]. The necessity of forming communicative competence for using a foreign language in different fields of human activity conditions the attention paid by teachers and researchers to a dialogue as the most common phenomenon of oral speech. Communicants' participation in a dialogue on a comprehensible topic and emotionally comfort conditions imply adequate acceptance of different conversational situations and choosing familiar roles.

The main purpose of the study is creating effective dialogical models suitable for practical use in learning a foreign language.

\section{Discussion}

Communicative strategies and approaches. Communication without any communication barrier is considered to be effective communication. The creation of effective dialogical models facilitate clearing communication barriers and transferring communication to more comfortable conversational situation: vocabulary maximally understandable for a conversation partner is used, familiar conversation topics are implied. "Communicants' language behaviour models depend both on their role in each certain act of conversation (verbal communication), and on the conditions and goals of such communication, as well as on certain constants such as any person's age, education, psychological make-up, social status, national and cultural background, etc." [3: 13]. Under the conditions of multinational groups and groups with mixed age communication success or unsuccess (failure) in many respects depends on approaches and strategies chosen by communicants.

O.S. Issers from the perspective of cognitive approach defines a communicative strategy "as a complex of speech acts aimed at achieving communicative goals, which includes planning the process of verbal communication depending on certain conditions of communication and communicants' individuality, as well as on the implementation of such a plan" [4: 100].

According to E.K. Kliuyev, a communicative strategy is "a part of communicative behaviour or communicative interaction, in which a range of different verbal and nonverbal means is used for achieving a communicative 
goal, and is a strategic result, at which a communication act is aimed" [5: 37]. V.B. Kashkin defines a strategy as a general framework, behaviour outline, "which can include also deviation from a goal in certain steps". Many strategies are ritualized, turn into conversational conventions losing their "rheme-specific qualities" and informational value", and a tactics (an approach) as "a combination of practical actions in a real process of talk exchange (speech interaction). A communicative tactics is a smaller scale of the communication process in comparison with a communicative strategy. It is relevant not to a communicative goal, but to a set of certain communicative intentions" [6: 132-136]. Therefore, a communicative strategy is a way of achieving communicative goals, and a communicative tactics consists of practical actions and communicative intentions.

Communicative structures of a dialogue. From the perspective of psychology the analysis of dialogical speech shall be based on the comprehension of interaction subjects as intersubjectivity dynamics, i.e. as a process of development of relations between certain subjects, forming of their assessment, emotions, values and purposes under mutual influence in the process of dialogic communication. "An utterance (as a conversational integral unit) can not be recognized as a unit of the last, top level of the language structure (above the level of syntax), because it is a part of fundamentally different relations (dialogic relations) incomparable with the linguistic relations of other levels..." [7: 304-305]. "Dialogic relations between utterances... belong to metalinguistics. They are disparate to any other possible linguistic relations of different elements both in the language system, and in a separate utterance" [Ibid: 286-287].

Intentional models of a dialogue represent interaction as a process targeted at the implementation of a plan, partners intentions, and achieving goal, and informational models outline a concept of interaction as a process of information interchange between the participants of a dialogue. More specific models of a dialogue represent separate stages of verbal interaction (start, the process itself, completion, assessment, change or influence, taking a decision) [8: 89-109].

A dialogue as a form of speech has a range of specific features, such as

1) substantial number of etiquette formulae, stereotypes, and set phrases;

2) unexpanded replication (reduced utterances);

3) situational conditionality;

4) proximity to internal speech by structural characteristics, etc.

These specific features open great opportunities for teaching foreignlanguage dialogue skills as early as the initial stage drawing close attention to the problem of adopting structural elements and characteristic linguistic properties of a foreign-language dialogue by students.

The interrelation between the strategical content of a dialogue and the specific character of its grammatical arrangement remains the most im- 
portant question to be answered. A number of researchers solves this problem relying upon the concept of intentionality. Intentionality in grammar means the relation between the semantic functions of grammatical forms and the intentions of a speaker with a communicative aim of an utterance and a text, the grammatical form capability of becoming one of the elements actualizing the general idea of verbal and cogitative activity. The determination of intentions in grammar implies the consideration of complex interaction of many contextual and sociolinguistic factors. In such case only the most frequent for them grammatical means can be specified. However, the recognition of this fact does not eliminate the question concerning grammatical ways of explicating dialogical strategies and tactics. The most important thing in this line of grammatical studies lies in the fact that grammatical forms allow (within bounds) for variation capable to translate speaker's intentions, which allows identifying the character of strategies applied by a speaker.

The analysis of the existing concepts of communicative strategies allows drawing a conclusion that communication strategies not being a factor directly designating an option of a dialogical structure, nevertheless, exert a great influence over it. Therefore, communication strategies can be used in the process of creating new systems of conditionally communicative strategic exercises for teaching dialogue grammar as a means allowing speeding up the process of forming not only communicative competence as a whole, but also flexible grammar and dialogical speech skills due to the improvement of the effectiveness of exercises being used.

A task for identifying and using different ranges of communicative strategies in the process of teaching a foreign language given to research teachers causes arguments and discussions related to the pendency of questions of the forms of implementing different strategies in different language structures. The question of the criteria of selecting strategical dialogue units and of using them when creating strategical exercises, as well as of the character of such exercises and forms and ways of consideration of individual strategies in the process of teaching dialogical speech is not solved.

The comprehension of a dialogue as the most common oral speech phenomenon reflecting all the regularities of the communication process as a whole is typical for present-day studies and researches. The consideration of communication as the interaction of subjects performed by means of sign vehicles and targeted at significant change of the condition, behaviour, and personal and semantic formations of partners defines the main goal of dialogical speech as exercising some or other influence over a dialogue partner. "Utterances of a dialogue at the psychological and relatively easy-to-observe level are oriented against each other. They correlate as a stimulus and reaction" [9: 305]. If a communicant upsets the right correlation, he/she causes relevant reaction of the other dialogue partner. The high significance of 
strategies in learning and teaching dialogical speech is conditioned just by this factor.

A dialogue as the most important phenomenon of unrehearsed oral speech is characterized by its spontaneity. That is why dialogical speech has a lot of compensation strategies and hesitation pauses allowing a speaker considering further re-planning of his / her speech in case of any unexpected reaction of a dialogue partner. Active application of compensation strategies makes a dialogue less lexically exact. The availability of speech mistakes, short sentences, dividing sentences into several communication units are typical for a dialogue. L.P. Yakubinsky notes that a dialogue is characterized not only by interchange of communicants' speech, but also by interruption of a dialogue partner, which is a characteristic of a emotionally charged dialogue. According to him, "in some respects we can say that just alternate interruption is typical for a dialogue in general" [10: 17-58].

Nevertheless, a high speech tempo typical for an everyday interpersonal dialogue is not a factor promoting the optimization of speech activity related to consideration, contestation of motives, choice of lexical means and grammatical structures. Instead, a high tempo of dialogical speech rather implies "the manner of a simple act of will having customary elements". Compared to a monologue (especially a written monologue) dialogic communication "implies making statements "at once" and even "anyhow"" [Ibid.].

Many defects of oral speech such as incomplete statements, poor structuredness, interruptions, self-commenting, contactors, repeating, hesitation elements, etc. are the necessary conditions of the successfullness and effectiveness of dialogic communication. A listener can not keep track of all grammatical and semantic relations of a text, and a speaker shall take it into account. In such case his / her speech will be understood and comprehended, especially if we are talking about the colloquial register.

A dialogue is typified as a primary and natural form of verbal communication, for which reason as a form of speech it is more often used in colloquial style of speech, but also can be represented in scientific, publicistic, and official style of speech.

Topics of a dialogue can change at random in the course of deployment of such a dialogue. Even in case of using scientific, publicistic, or official speech under condition of possible preparation of any preliminary script of a dialogue the deployment of such a dialogue by each of dialogue partners will be spontaneous, because in absolute majority of cases scripts and their implementation can not be absolutely identical, and the utterances and reactions of a dialogue partner are unknown or can become unpredictable.

A business dialogical discourse, which is interpreted as a socially conditioned speech event functioning in the institutional and production sphere, is marked for its certain orderliness and arrangement, and is characterized primarily by a high degree of topic fixity. Topical coherence is pro- 
vided by adherence to the maxim of relevance, according to which the propositional content of an utterance shall correspond to the main topic of discourse. At the language level it is implemented through repeating key lexical units. Breach of this postulate can cause unsuccess, communication failure, and even breach of communicants' relations.

Speech exactness and clarity, its comprehensibility, brevity, as well as cost effectiveness of means, dialogue partners' ability of expressing their thoughts in full eliminating their varied interpretation - all these requirements reflect the maxim of way of action.

Adherence to the maxim of quantity can cause certain difficulties, because requirements to the degree of informational content of an utterance vary according to the level of communicants' level of knowledge, their social status, and emotional condition. As a part of business dialogical discourse utterances are rather often characterized by lack of information, especially in cases, when a communication participant tries to cover up facts intentionally.

This breach in some measure affects also the maxim of quality [11: 220-234]. Although the requirement concerning the adherence to this maxim is obligatory for business partners, in real communication we observe the phenomenon, which is called in psychology a conflict between the due and the real. On the one hand, a person tries to behave properly, and on the other hand, such a person wants to satisfy his / her needs, satisfaction of which is often related to any breach of moral and ethical standards [12].

Therefore, we can draw a conclusion that the Grice maxims belong rather to ideal, desired dialogical communication different from the existing one.

Studies of the interaction-and-role structure of dialogical communication brought researchers to the development of dialogue hierarchical categories [13], which appear relevant in case of selecting dialogues for the initial stage of teaching a language with consideration of communication strategies, because they reflect the role status of dialogue partners.

The complexity of the social and conversational problem being solved by communicants allows separating dialogues themselves [Ibid.]. According to their role forms of dialogues themselves such as domination, control and mutual control are differentiated. A domination-type dialogue is the most typical dialogue for foreign-language communication of beginners working in paired groups, each of which consists of a teacher and a student, a native speaker is a foreign person, because such type dialogue is defined by stable unequal communicative roles of dialogue partners. The role of a communication leader is reserved for a teacher (native speaker) almost all the time, because of not only language-specific, but also status-specific reasons.

Every communication role includes characteristic lines of strategic behavior conditioned by communicative aims and dialogical orientation of dialogue partners, who determine a possible set of communication strategies typical for each certain case, which can be individual and role-based. It goes 
without saying that individual strategies be of the utmost interest for researchers, but for methodical purposes it is necessary in the first turn to perform comprehensive consideration of the strategical content of communication roles, which can be set by students in their exercises, which universalizes and individualizes the training process at the same time.

I.I. Vasilyeva defines 3 main type of dialogical interaction complexity.

The first type is monological communication, which consists in the unilateral influence of one of the partners over the other partner. The descriptive unit of such type communicative interaction is a separate pseudomonological utterance. The next more complex level of communicative interaction is unilateral dialogical communication, which consists in the fact that a partner not only conveys a message to the other partner, but also involve him / her in the communication process: such a partner conveys a message too. A dialogical structure such as a cycle corresponds to this type communicative interaction. This type is called unilateral dialogical communication, because communicative initiative belongs only to one of the partners. If such dialogical communication initiative is transferred by one partner to the other partner and a subject acting as a respondent in one cycle of interaction subsequently initiates a new interaction cycle by himself / herself, such a type can be conditionally called bilateral dialogical communication, where the act of bilateral initiative is emphasized. In the opinion of psychologists, such a type of communicative interaction has more complex structure consisting of linked dialogical cycles [14].

The last subject-and-subject type dialogue is considered in this paper as the main object of study. In this type of dialogue the two main roles (initiator and respondent) are preserved and the domination of a leader is not strongly-pronounced, recapturing the initiative is allowed in the process of achieving a communication goal, for example, at the stage of preanswering or postcentral strategic exchange.

As a communication leader and a respondent fulfilling different functions use different sets of strategies, it is necessary to define and differentiate the strategies of each role in the communicative structure of a dialogue and their subsequent differentiated use in organizing the process of teaching and creation of a system of exercises for learning dialogue grammar. Therefore, any choice for performing strategic analysis of the interaction-and-role structure of a such type dialogue is conditioned by its relatively simple and specific aspects favourable for the initial stage of training, such as follows:

a) availability of only two communicative roles;

b) relative stability of roles, which allows defining relevant strategies in provisions for performing exercises under condition of work in pairs [15].

Formally the main unit of a dialogue is a dialogical unity, i.e. a semantic association of several utterances, representing the exchange of views and utterances, each subsequent of which depends on the previous one. The vol- 
ume and the character of utterances can depend on different factors, which are dialogue partners' individuality and their certain communicative and speech strategy and tactics, general speech culture of dialogue partners, formality degree of a certain situation, factor of "a potential listener", i.e. such a listener or a spectator, who is present, but does not participate in a dialogue. The character of utterances is affected by the status of dialogue partners, as well as so called code of communicants' relations.

\section{Characteristics of the experimental study}

Introduction to the study. From the point of view of psycholinguistics, a communicative strategy is defined as "a way of organizing verbal behavior in accordance with the plan and the integration of a communicant" [16: 85]. Simulated communication involves three pragmatic levels of interpretation: social, psychological and communicative. The social roles of communicants influence the choice of a communicative strategy. In the proposed player positions psychological contact is characterized by the degree of disposition towards communication. Unsymmetrical contacts (teacherstudent) affect the dialogue development, where limitations of choice of tactic forms typical for informal communication and verbal self-expression get involved. Wider prospect of a dialogue is provided due to the equal social roles of participants, where understanding of the emotional state of dialogue partners and cooperation based on the interested perception of information transmitted, provide certain volume of an act of speech interaction.

The aim of the study is learning the process of language-based interaction under the conditions of situations simulated.

Methods of the study. For the purpose of collection and analysis of linguistic material, the methodology of observation, experiment, and the method of discourse extracted was used. Controllability of experimental conditions, reproducibility of results and the possibility of manipulating one or more variables are the most important factors for choosing a method of study.

Description of the experiment. This linguistic experimental study was conducted with a sufficient number of subjects and the necessary amount of stimulating materials in order to obtain statistically significant results. The experiment was conducted with elements of conscious influence on the process of natural language interaction. Manipulation of the process was due to the unexpected introduction of a new incentive (stimulus).

Participants: The experiment involved 28 foreign students and undergraduates (10 women and 18 men) at the ages from 20 to 25 from Vietnam, Scotland, Italy, and China, who study Russian as a foreign language.

During the experiment the participants were divided into two groups. One of the groups was suggested participating in dialogues without incentive cards on a proposed topic (situations 1-3), and the other group in the process 
of dialogical interaction received after a certain period received an incentive card. The following two blocks of cards were proposed as drivers.

The $1^{\text {st }}$ block: tasks for further dialogical communication

Situation 1. Invite your friend to house.

Situation 2. Ask your friend about his / her plans for a vacation.

Situation 3. Ask your friend to help you in translating a complex text.

Situation 4. Your common friend will soon have a birthday. Seek advice from your another friend concerning to a present for your common friend.

The $2^{\text {nd }}$ block: incentive cards for continuing dialogue or changing speech intentions in the process of dialogue.

Situation 1. Cards with the words "address", "motive / reason", "food / drinks / treats", "guests", and "pets".

Situation 2. Cards with the words "online booking", "plane", "hotel", "coast / mountains", "cities", "excursions", and "two weeks".

Situation 3. Cards with the words "refusal" and "consent".

Situation 4. Cards with the words: "hobbies", "the best present", "the worst present", "money", "gift card", "present made with your own hands".

Results of the experiment. As a result of conducted researches, a corpus of extracted dialogues consisting of 56 speech situations was compiled. Transcripts include text decoding, false starts, hesitation pauses, feedback markers and other discursive marking.

During the experiment the authors confirmed the key provisions of Clark dialogue interaction model [17], according to which the basis of any dialogic communication is the Principle of joint activity, which consists of coordinated individual actions of dialogue partners targeted at achieving a set communication goal. In dialogues coordination is performed with the use of feedback markers, which serve as an explicit confirmation of the success of any communicative act [Ibid: 16], examples 1.1-1.2 (see below):

1.1 .

A: I can... in Krasnoarmeyskaya Street...

(А: Это я могу на улице Красноармейской...)

B: Yes, yes. And by bus number 85 .

(Б: Да, да. И на автобусе 85.)

A: OK. Understand.

(А: Хорошо. Поняла.)

1.2 .

A: Good luck! When you come back, you will tell me everything, where you were, what places you attended.

(А: Удачи тебе. Когда вернешься, ты мне расскажешь все, где ты была, что посещала.)

B: OK, I'll tell you everything. Bye-bye!

(Б: Хорошо, все расскажу тебе. Пока!) 
A: Bye!

(А: Пока!)

Joint activity is also shown when using echo-questions: examples 1.3.-1.6.

1.3 .

A: Do you translate from Russian into English?

(A: Переводить с русского на английский язык?)

B: No, from English into Russian. Quite the reverse.

(Б: Нет, с английского на русский. Наоборот.)

A: Quite the reverse?

(A: Наоборот?)

B: Yes. Have you already done everything?

(Б: Да. А ты уже все сделала?)

1.4 .

A: After classes I sit at home and do nothing.

(А: После занятий я сижу дома и ничего не делаю.)

B: Nothing? And do you want to come to my place today?

(Б: Ничего? А ты не хочешь ко мне сегодня в гости прийти?)

1.5 .

A: Interesting. Will be any excursion there?

(А: Интересно. Там будет экскурсия?)

B: Excursion? I don't like excursions. I don't like such travel offers. I like traveling alone, for no particular reason.

(Б: Экскурсия? Я не люблю экскурсии. Мне не нравятся такие туры. Я люблю сам путешествовать, просто так.)

1.6. for you?

A: Help me with this text and I will buy a chocolate or something else

(А: Давай ты поможешь мне с этим текстом, а я тебе куплю шоколадку или что-нибудь?)

B: Chocolate? No, I can't. You heard me, I'm busy.

(Б: Шоколадку? Нет, я не могу. Я занята, я же сказала.)

The coordination of joint actions of dialogue partners is achieved due to their common position. In this experiment, the level of proficiency in Russian as a foreign language is the common position of the dialogue pertners. However, it should be noted that "not all categories can function equally for members of different national, linguistic, and cultural communities" [18: 582]. For that very reason communication often failed: example 1.7.

1.7.

A: And you will fly by plane?

(A: А ты полетишь на самолете?)

B: Of course, by plane! From Krasnodar.

(Б: Конечно, на самолете! Из Краснодара.)

A: And what would you like: to work in Russia or to live in Italy? 
(A: А ты как бы хотел: работать в России или жить в Италии?)

B: Life often changes. I don't know yet. I will be in Rome for several days and I will stay in a hotel there.

(Б: Жизнь часто изменяется. Я пока не знаю. Я буду в Риме несколько дней и там, в гостинице буду жить.)

The analysis of the language material allowed us to identify the following causes of communicative failures:

- language barrier - the difference between the communicants' volume of active vocabulary and the level of skills in using it;

- semantic communicative barriers, by reason of which an ambiguous interpretation of the semantics of a word led to misperception;

- lack of background knowledge of one of communicants;

- communicative discomfort and mutual misunderstanding between communicants;

- discrepancy of communicative intentions of dialogue partners;

- discrepancy of the interests of communicants, when the level of information perception is significantly reduced, if a topic discussed is not interesting for one of dialogue partners;

- evading a direct answer by one of communicants;

- contravention of principle of politeness;

- negative assessment of dialogue partner's speech actions.

Moving from one topic of conversation to another, communicants follow the principle of mutual responsibility or the principle of cooperation [11:217]. According to this model, the communicative act consists of two phases: the phase of presentation and the phase of acceptance. In the process of communication, dialogue partners add some new information, which is considered to be their common position until it is accepted at the second stage: example 1.8.

1.8 .

A: I will create my own excursion myself. Because I often change my route. Therefore, I want everything to depend on me.

(А: Я сама создам свою экскурсию. Потому что я часто меняю свой путь. Поэтому я хочу, чтобы зависело все от меня.)

B: Do you remember? Hmm... well, yes, in the second year we were taught how to create an excursion? That's why you do the right thing creating your own excursion... and it's more convenient.

(Б: Помнишь А... ну да, на втором курсе мы учили, как создать экскурсию? Поэтому ты правильно делаешь, что создаешь свою экскурсию... и это удобнее.)

Communicants create "a related pair, an elementary frame, through which the participants of a conversation show the result of their analysis of each other's actions [19]. Each participant should analyze the actions of his / her partner in order to perform an appropriate response action" [20:60]. 
Depending on a topic of a dialogue, the intentions of speakers also change: in some cases self-expression predominates, and in other cases the influence over a dialogue partner predominates. In accordance with a situation, lexical means also change: "the means of expressing complaisance, politeness, and respect, as well as the system of means of "comfort environment” [21: 44]: “Good luck!", “Wow!", "I'm up for”!”. Examples 1.9, 1.10. 1.9 .

A: OK. See you! Bye!

(А: Ага, давай, пока!)

B: Bye!

(Б: Пока!)

1.10 .

A: Look, well..... help me to translate the text.

(А: Слушай, ладно..... ну помоги мне перевести текст.)

B: Sorry, but I can't really!

(Б: Прости, но я никак!)

The use of lexical units such as "OK" and "come on", which are now extremely popular being widely used in the process of communication ... can mean consent, refusal, gratitude and even mistrust. Besides, with the help of these phrases dialogue partners often end their conversation and use them at parting in situations of communication in the modern language environment" [22: 168].

The use of the principle of minimal joint efforts is noted in a group of communicants, who were offered only topics of dialogues without incentive cards: examples 1.11.-1.12.

1.11 .

A: Hi!

(А: Привет.)

B: Hi.

(Б: Привет.)

A: I want to invite you to my place.

(A: Я хочу тебя пригласить в гости.)

B: I agree. When?

(Б: Я согласен. Когда?)

A: Tomorrow evening at seven o'clock.

(А: Завтра, в семь вечера.)

B: OK, I'll come.

(Б: Хорошо, я приду.)

1.12 .

A: Are you going out somewhere for a vacation?

(А: Ты собираешься куда-нибудь поехать на каникулы?)

B: Yes, I'm going to China.

(Б: Да, в Китай.) 
A: Good. = What?

(А: Хорошо. = Что?)

B: What? = To China.

(Б: Что? = В Китай)

The speakers pronounced standard nominations of minimum length, which were sufficient for the listeners to respond to a statement.

Therefore, psycholinguistically, communication tasks at different stages of training can be presented in the form of a set of exercises (training and conditionally communicative) to master the means and methods of implementing speech interaction aimed at developing speech skills. Pseudocommunicativeness of such tasks is eliminated due to the availability of a training task and incentives aimed at overcoming the communicative problem through a communication strategy. Training exercises are used at the preliminary stage of teaching (elementary and basic levels of language proficiency), and conditionally communicative exercises are used at the strategic stage (I certification level). The preliminary stage consist of two stages: the orientation stage and the training stage. At the orientation stage prior to the start of completing a communication task dialogue partners get acquainted with a block of grammatical, linguistic and strategic means necessary for completing the task. At the training stage they train complex phonetical, lexical and grammatical constructions. At the strategic stage information gap is created and filled, communication tasks are completed, and communicative problems are solved with the help of communicative strategies.

Strategic manipulation can be used for learning and adopting of dialogical structures. Thus, for example, it is possible to extend the elementary cycle with the help of structural strategic components, request additional information, introduce a new goal, and a scenario of avoiding a direct answer or a respectful refusal.

In dialogical communication, the roles of communicants are often distributed unevenly: a communicant with a higher level of language proficiency is an active dialogue partner, while a passive speaker gives the partner the opportunity of taking the initiative, thereby using less lexical units and generating minimal syntactic constructions.

The introduction of a incentive (stimulus) entails a drastic change in the situation - communicants interchange their roles and a new stimulus serves as a signal for a subsequent exchange. It should be noted that the leader of a dialogue immediately changes the pitch, tempo and loudness of speech.

\section{Conclusion}

Therefore, a module of communicative practice is to be introduced in the system of teaching a foreign language, where not a single talk exchange 
(action and reaction) or an act of speech interaction on a given topic, but a simulated dialogue will be used as a basic unit.

It is proposed to use two following models of interaction as the basis of a simulated dialogue: the actual model including two dialogue partners, and the informative model containing a subject of speech. As shown by the study, the development of dialogical communication is facilitated due to the use of drivers (incentives) aimed at facilitating communication. If in the course of speech actions the goal of communication is achieved, but communicants spend a minimum amount of lexical units, then different incentives for the leader and for the responder will promote further development of dialogical communication and provide the coherence of speech acts in which the reaction of one act serves as an action for the next act.

When using incentives, communicants will be forced to combine grammatical and lexical units in the mode of continuous speech interaction continuously. At various stages of teaching, the topics of dialogues and drivers incentives will be changed and will become more complex: from elementary everyday topics to scientific discussions.

The consideration of the content of dialogical structures allows us drawing the following conclusions.

1) Communication strategies used by a communicant are closely related to his / her communicative role as a leader or a responder.

2) There is a number of behavioral positions, which are typical only for one of the roles, to which specific sets of communicative strategies correspond. In the process of teaching the grammatical expression of dialogical speech, the role strategies of communicants are used.

3) At the initial stage of teaching language, by taking into account communication strategies, a complicated dialogical cycle containing at least one strategic communicative move in the speech production of one of dialogue partners is used as a unit of teaching dialogue grammar.

4) For a communication initiator strategic moves such as precentral move, strategically communicative step, alternative request, or appeal for help can be used, and for a responder all kinds of support, additional requests, and pre-answers can be used.

\section{References}

1. Chomsky, N.: Aspects of the theory of syntax. Cambridge: MIT Press (1965)

2. Milrud, R.P., Maksimova, I.R.: Communicative competence as students' readiness for foreign-language communication // Language and culture, 38 (2017)

3. Nikolova, A.: Speech tactics and language markers of disagreement and proneness to conflict in the process of inciting to action // Rusistika 2003: Language, communication, culture. University publishing house "Yepiskop Konstantin Preslavsky". Shumen. pp. 13-19 (2003)

4. Issers, O.S.: Communicative strategies and tactics of Russian speech. M.: KomKniga /URSS (2006) 
5. Kliuyev, Ye.V.: Speech communication. M.:PRIOR (1998)

6. Kashkin, V. B.: Introduction to the communication theory: Tutorial. Voronezh: Publishing house of Voronezh State Technical University (2000)

7. Bakhtin, M.M.: Problem of text in linguistics, philology, and other humanities. Phylosophical analysis experience. // M. M. Bakhtin. Esthetics of verbal creative activities. M.: Iskusstvo (1979)

8. Cohen, A.D., Scott, K.A.: Synthesis of approaches to Assessing Language Learning Strategies // Language Learning Strategies around the World. pp. 89-109 (1996)

9. Paducheva, Ye.V.: Utterance and its correlation with reality. M.: URSS (2001)

10. Yakubinsky L.P.: About dialogical speech. // Yakubinsky L.P. Selected texts: Language and its functioning. M. pp. 17-58 (1986)

11. Grice, G.P.: Logic and verbal communication // The new in foreign linguistics. M.: Progress. Edition XVI: Linguistic pragmatics. pp. 220-234 (1985)

12. Abulkhanova-Slavskaya, K. A.: Life strategy. M.: Mysl (1991)

13. Yotov, Ts.D.: Linguistics of simultaneous speaking, University, St. Clement of Ohrid publishing house (1991)

14. Vasilyeva, I.I.: Psychological aspects of dialogue. Dissertation of a Candidate of Psychological Sciences. M. (1984) URL: http://www.dissercat.com/content/ psikhologicheskie-osobennosti-dialoga

15. Daver, M.V., Mikheeva, T.B.: Communicative strategies of discourse in teaching foreignlanguage dialogue. Strategic approach: monograph // Saarbrucken (Germany): LAP LAMBERT Academic Publishing (2016)

16. Borisova, I.N.: Aim categories and text analysis aspects // Speech genres: Collection of scientific articles. 2nd Edition. Saratov: Publishing house of the State Scientific Training Center "College" (1999)

17. Clark, H.H., Wilkes-Gibbs, D.: Referring as a collaborative process // Cognition. 22 (1) (1986)

18. Ereshchenko, M.V., Kachan, Yu.E.: Text authenticity as a part of the communicative and cognitive approach to teaching a foreign language // Cognitive language research. 29. pp. 578-583 (2017)

19. Clark, H.H., Schaefer, E.F.: Contributing to discourse // Cognitive Science. 13 (1989)

20. Nayman, Ye.A.: Theory of speech acts in critical perspectives of linguistic anthropology and sociolinguistics // Language and culture. 4 (32) (2015)

21. Devkin, V.D.: Colloquial German. Syntax and vocabulary. M.: International relations (1979)

22. Minakova L.Yu. Influence of situational context over the adequacy of understanding authentic speech in teaching foreign-language discourse // Language and culture. 1 (33) (2016)

Information about the authors:

Mikheeva T.B. - D. Sc.(Education), Don State technical university (Rostov-on-Don, Russia). E-mail:mitata@yandex.ru

Ereshchenko M.V. - Ph.D., Associate Professor, Don State technical university (Rostov-onDon, Russia). E-mail: mar.ereshchenko@yandex.ru 